\title{
Effects of osmolality, bicarbonate and buffer on the metabolism and motility of testicular, epididymal and ejaculated spermatozoa of boars
}

\author{
J. L. Dacheux $\dagger$, T. O’Shea* and M. Paquignon $\ddagger$ \\ I.N.R.A. Station de Physiologie de la Reproduction, Nouzilly 37380, † Laboratoire Physiologie \\ Comparée, Faculté des Sciences, Tours 37000, and $\ddagger$ I.T.P., 149 rue de Bercy, Paris $12^{\mathrm{e}}$, France
}

\begin{abstract}
Summary. Spermatozoa were collected from the rete testis of conscious boars, from the cauda epididymidis by retro-flushing, and by ejaculation. Testicular spermatozoa showed no progressive motility, and that of ejaculated was greater than that of epididymal spermatozoa. Glycolysis and respiration of testicular spermatozoa, while lower than that of the more mature cells, were only slightly affected by the incubation conditions. Epididymal spermatozoa converted $83 \%$ of the glucose they utilized to $\mathrm{CO}_{2}$ or lactate, but testicular cells converted only $35 \%$ to these metabolites. Synthesis of lipid was greatest by testicular spermatozoa. With the more mature cells hyperosmolar conditions depressed $\mathrm{CO}_{2}$ production, but increased lactate production, and these changes were greater for ejaculated than for epididymal spermatozoa. Glycolysis plus respiration of these cells was related to their motility. These results were interpreted as showing increasing motility, glycolysis and respiration with maturation, but also decreased synthetic capacity and increased sensitivity to the environment.
\end{abstract}

\section{Introduction}

That boar spermatozoa undergo changes as they pass through the epididymis has been inferred for a considerable time (Lasley \& Bogart, 1944) but it was only the introduction of cannulation techniques (Voglmayr, Waites \& Setchell, 1966) that enabled tissue-free testicular spermatozoa to be obtained. Changes in metabolism during sperm maturation in some species have recently been reviewed (Voglmayr, 1975). By adaptation of the techniques used in the ram it is possible to collect boar spermatozoa at various stages of maturation. Because the natural fluids in which these spermatozoa are suspended are different (Mann, 1975), a comparison was made of the metabolism of washed cells. The osmotic pressures of the native suspending fluids also differ (Levine \& Marsh, 1971), and since osmotic pressure affects ejaculated spermatozoa (Blackshaw \& Emmens, 1951; Stevermer, First \& Hoekstra, 1964), this was included as one of the main variables in a comparison of the metabolism of boar spermatozoa at various stages of maturation.

\section{Materials and Methods}

Sperm samples. Large White boars aged 1-2 years were used. Ejaculated spermatozoa were from the 'sperm rich' fraction of ejaculates collected manually with a 'dummy sow' and filtered through gauze. The seminal plasma was removed after centrifugation at $900 \mathrm{~g}$ for $10 \mathrm{~min}$. The

\footnotetext{
* Present address: Department of Physiology, University of New England, Armidale, New South Wales, Australia.
} 
spermatozoa were then washed twice at $25^{\circ} \mathrm{C}$ with the phosphate-buffered washing diluent (PBW: see below). Epididymal spermatozoa were obtained from the cauda epididymidis within 30 min of slaughter or castration of the animal. The tubule of the cauda epididymidis was flushed by injection of paraffin oil into the vas deferens and the spermatozoa were collected from a freed loop of the tubule. The cell suspension collected (about $4 \mathrm{ml}$ ) was diluted in $50 \mathrm{ml} \mathrm{PBW}$ at $25^{\circ} \mathrm{C}$ and washed twice at $25^{\circ} \mathrm{C}$ by centrifugation at $900 \mathrm{~g}$ for $10 \mathrm{~min}$.

Testicular spermatozoa were obtained in rete testis fluid collected from conscious boars. The extratesticular rete was cannulated as described previously for the ram (Voglmayr et al., 1966; Voglmayr, Scott, Setchell \& Waites, 1967). The rete testis fluid was drawn caudally into a vessel, cooled to $4^{\circ} \mathrm{C}$ as described for the ram (Edwards, Dacheux \& Waites, 1976). The boars were kept in a normal pen and the catheters remained patent for up to 8 days, with a fluid flow rate of about $2 \cdot 5-3 \mathrm{ml} / \mathrm{h}$ and $150 \times 10^{6}$ spermatozoa $/ \mathrm{ml}$. Samples were removed after collection for $12 \mathrm{~h}$. In the present study some testicular spermatozoa were obtained from animals cannulated and maintained under anaesthesia for several hours before slaughter. Spermatozoa were separated from the testicular fluid by centrifugation and washed once with $\mathrm{PBW}$.

Diluents. All diluents contained $5 \mathrm{~mm}-\mathrm{KCl}, 2 \mathrm{~mm}-\mathrm{MgCl}_{2}, 1 \mathrm{~mm}-\mathrm{CaCl}_{2}$, sodium benzyl penicillin (500 000 i.u./l) and streptomycin sulphate $(0.5 \mathrm{~g} / 1)$. Spermatozoa were washed and resuspended in the phosphate-buffered washing diluent (PBW) which also contained $1 \mathrm{~mm}$ $\mathrm{Na}_{2} \mathrm{HPO}_{4}$, adjusted to $\mathrm{pH} 7.4$ with $\mathrm{NaH}_{2} \mathrm{PO}_{4}$ and to $310 \mathrm{mosmol} / \mathrm{kg} \mathrm{H}_{2} \mathrm{O}$ (with a Fiske Osmometer) with $\mathrm{NaCl}$ (about $145 \mathrm{~mm}$ ). Spermatozoa were not in PBW for longer than $1 \mathrm{~h}$.

When comparing buffers, incubation diluents containing 40 - or 60 -mM phosphate buffer (sodium salts), or $60 \mathrm{~mm}$-Tris ((hydroxymethyl) aminomethane)-HCl buffer (Tris buffer), or 60 mM- $N$-Tris ((hydroxymethyl) methyl 2-aminoethane sulphonic acid)-HCl buffer (Tes buffer), and $10 \mathrm{~mm}$-glucose were used. To study the effect of osmotic pressure $60 \mathrm{~mm}$-Tris- $\mathrm{HCl}$ and 40 mM-phosphate-buffered incubation diluents containing $10 \mathrm{mM}$-glucose and with and without 12 mM-sodium bicarbonate were used. The osmotic pressure was varied by altering the amount of $\mathrm{NaCl}$ to obtain diluents with $150,190,250,310,370$ or $430 \mathrm{mosmol} / \mathrm{kg}$ (Tris) and 190, 250, 310 or $430 \mathrm{mosmol} / \mathrm{kg}$ (phosphate). The $\mathrm{pH}$ and osmotic pressure of diluents containing sodium bicarbonate were adjusted after addition of the bicarbonate.

Incubation system. Spermatozoa suspended in $0.5 \mathrm{ml} \mathrm{PBW}$ were incubated at $37^{\circ} \mathrm{C}$ with gentle shaking for $3 \mathrm{~h}$ in 10-ml Erlenmeyer flasks containing $0.5 \mathrm{ml}$ of the appropriate incubation diluent and $1 \mu \mathrm{Ci}\left[\mathrm{U}-{ }^{14} \mathrm{C}\right]$ glucose (sp. act. $316 \mathrm{mCi} / \mathrm{mmol}$ : Radiochemical Centre, Amersham, England). The final concentration of spermatozoa in the flasks was about $1 \times$ $10^{8} / \mathrm{ml}$. Buffer concentrations during incubation were $30 \mathrm{~mm}$-Tris, $30 \mathrm{mM}$-Tes, and $20 \mathrm{~mm}$ - or 30 mM-phosphate. The osmotic pressures referred to in the text are the final values obtained during incubation in the flasks.

Carbon dioxide production. The flasks were fitted with air-tight stoppers and plastic hanging wells. $\mathrm{CO}_{2}$ production was estimated as described previously (Edwards et al., 1976). At 10 min before the end of incubation $0.2 \mathrm{ml}$ hyamine hydroxide $(1.0 \mathrm{M}$ in methanol) was injected into the hanging wells. The $\mathrm{CO}_{2}$ dissolved in the buffer was liberated by the injection of $0.2 \mathrm{ml}$ $1 \mathrm{M}-\mathrm{H}_{2} \mathrm{SO}_{4}$ into the flasks at the end of the incubation. The hanging vials were removed $1 \mathrm{~h} \mathrm{later,}$ wiped, and placed in scintillation vials containing $10 \mathrm{ml}$ scintillation mixture (toluene :triton, $2: 1$ $\mathrm{v} / \mathrm{v}$; PPO $4 \mathrm{~g}$ and POPOP $0.1 \mathrm{~g} / 1$ toluene). Radioactivity in the trapped $\mathrm{CO}_{2}$ was estimated after the chemiluminescence had disappeared (at least $24 \mathrm{~h}$ ). Spermatozoa incubated under the same conditions but with the $\mathrm{H}_{2} \mathrm{SO}_{4}$ added at the start of incubation gave background values for each treatment.

Incorporation of glucose into lipids. When the flasks were opened the incubation medium was centrifuged and the supernatants removed. After washing in $2 \mathrm{ml} \mathrm{PBW}$ containing $50 \mathrm{~mm}-$ glucose and $50 \mathrm{~mm}$-lactate the spermatozoa were extracted three times with chloroform : methanol $(2: 1 \mathrm{v} / \mathrm{v})$. The lipid extract was washed once with $0.9 \%(\mathrm{w} / \mathrm{v}) \mathrm{KCl}$ and four times with methanol:water $(1: 1 \mathrm{v} / \mathrm{v})$. The washing was judged to be satisfactory because there 
was no radioactivity in the aqueous phase at the last wash. The extracted lipid was dried under $\mathrm{N}_{2}$ and dissolved in scintillation fluid for estimation of the radioactivity present in the lipids.

Lactate production. The supernatants from the incubations were deproteinized with $0.2 \mathrm{ml}$ 3.6 M-perchloric acid, neutralized with $5 \mathrm{~N}-\mathrm{KOH}$, and lactate was estimated enzymically. Glucose levels were measured enzymically on the same supernatants from the epididymal spermatozoa. With the epididymal cells the $\left[{ }^{14} \mathrm{C}\right]$ lactate formed from $\left[{ }^{14} \mathrm{C}\right]$ glucose was measured after separation by paper chromatography with butanol :acetic acid: water $(4: 1: 5$ by vol.) as the eluant. This was more difficult with the testicular cells because of the greater diversity of labelled products formed, but $\left[{ }^{14} \mathrm{C}\right]$ glucose and $\left[{ }^{14} \mathrm{C}\right]$ lactate were isolated from some replicates by paper chromatography.

Motility of spermatozoa. The percentage of motile spermatozoa and the progressive motility of the cells were assessed after the $3 \mathrm{~h}$ incubation (Paquignon, Dacheux \& Courot, 1977) by using aliquots of sperm suspension which were not treated with acid.

Statistical analyses. For a preliminary experiment mean values were compared with Duncan's multiple range test (Duncan, 1955). Analyses of variance were used on the data from the other experiments. Partitioning of treatment sums of squares was carried out with respect to the effects of osmotic pressure and its interactions by using matrices of orthogonal polynomial coefficients (Fisher \& Yates, 1963). The terminology ' $L$ ' and ' $Q$ ', taken from Cochran \& Cox (1957), indicates the linear regression (L) and the deviation from linearity or quadratic curvature (Q). Only the relevant portions of the analyses of variance are given in the tables or text, and some data, although examined by analysis of variance, are presented as mean \pm standard error (s.e.m.).

\section{Results}

\section{Ejaculated spermatozoa}

Comparison of buffers. In a preliminary experiment $30 \mathrm{~mm}$-phosphate, $20 \mathrm{~mm}$-phosphate, 20 mM-phosphate $+6 \mathrm{~mm}$-bicarbonate, and $30 \mathrm{~mm}$-Tris at $\mathrm{pH} 7.4$ were compared for 4 ejaculates. After incubation for $3 \mathrm{~h}$ there were no differences in the lactate production, percentage of motile spermatozoa and progressive sperm motility. Production of $\mathrm{CO}_{2}$ was 1.06, 1·26, 2.16, and 2.12 $\mu \mathrm{mol} / 10^{8}$ spermatozoa in $3 \mathrm{~h}$ with $30 \mathrm{~mm}$-phosphate, $20 \mathrm{~mm}$-phosphate, $20 \mathrm{~mm}$-phosphate +6 mM-bicarbonate, and $30 \mathrm{~mm}$-Tris respectively. Examination of the data with Duncan's multiple range test showed that $\mathrm{CO}_{2}$ production with $20 \mathrm{~mm}$-phosphate $+6 \mathrm{~mm}$-bicarbonate or with Tris was greater $(P<0.05)$ than that with $20 \mathrm{~mm}$ - or $30 \mathrm{~mm}$-phosphate.

In a second experiment $30 \mathrm{~mm}$-Tris and $30 \mathrm{~mm}$-Tes at pH 7.4 with and without addition of 6 mM-sodium bicarbonate were compared for 6 ejaculates. Again there were no differences in the percentage of motile spermatozoa and in their progressive motility; $\mathrm{CO}_{2}$ production was 1.81 , $2.44,0.81$, and $1.94 \mu \mathrm{mol} / 10^{8}$ cells in $3 \mathrm{~h}$ with Tris, Tris + bicarbonate, Tes, and Tes + bicarbonate respectively. The effects of buffer and bicarbonate addition were both significant $(P$ $<0.001$ ). Lactate production was decreased from 0.57 to $0.47 \mu \mathrm{mol} / 10^{8}$ cells over $3 \mathrm{~h}$ by addition of bicarbonate to Tris buffer but was increased from 0.55 to $0.59 \mu \mathrm{mol} / 10^{8}$ cells over $3 \mathrm{~h}$ by addition of bicarbonate to Tes buffer (buffer $\times$ bicarbonate interaction: $P<0.05$ ).

Because of these results, Tris was subsequently used as the main buffer in factorial experiments which could be statistically examined with analyses of variance; phosphate was used to a lesser extent.

Effect of $\mathrm{pH}$ of buffer. This was studied for 4 ejaculates with Tris-HCl buffer at pH 7.2, 7.4 and 7.6, and with final osmotic pressures of $280,310,340$ and $370 \mathrm{mosmol}$. There were no interactions between $\mathrm{pH}$ and osmotic pressure; $\mathrm{CO}_{2}$ production and sperm motility were not altered by change in $\mathrm{pH}$. Lactate production $\left(\mu \mathrm{mol} / 10^{8}\right.$ cells over $3 \mathrm{~h}$ ) increased linearly $(P<0.001)$ as the $\mathrm{pH}$ of the medium was raised (mean \pm s.e.m. $0.43 \pm 0.05$ at $\mathrm{pH} 7.2 ; 0.55 \pm 0.05$ at $\mathrm{pH} 7.4$; 
Table 1. Effect of osmotic pressure and $6 \mathrm{~mm}$-bicarbonate on the motility of boar spermatozoa after incubation and on their production of $\mathrm{CO}_{2}$ and lactate (measured enzymically) during incubation, which was for $3 \mathrm{~h}$ at $37^{\circ} \mathrm{C}$ in Tris- $\mathrm{HCl}$ buffer $\left(n=4\right.$, except for $\mathrm{CO}_{2}$ production by testicular spermatozoa where $n=6$ )

\begin{tabular}{|c|c|c|c|c|c|c|c|c|c|}
\hline \multirow[b]{2}{*}{ Sperm type } & \multirow[b]{2}{*}{ Bicarbonate } & \multicolumn{6}{|c|}{ Osmotic pressure (mosmol) } & \multirow[b]{2}{*}{ s.e.m.* } & \multirow[b]{2}{*}{ d.f. } \\
\hline & & 230 & 250 & 280 & 310 & 340 & 370 & & \\
\hline \multicolumn{10}{|c|}{$\%$ Spermatozoa motile } \\
\hline Ejaculated & - & - & - & $55 \cdot 5$ & $55 \cdot 0$ & 55.9 & $53 \cdot 4$ & $1 \cdot 215 \ddagger$ & 33 \\
\hline Ejaculated & - & $57 \cdot 1$ & $60 \cdot 0$ & 55.0 & $54 \cdot 1$ & - & - & $0.794 \ddagger$ & 12 \\
\hline Epididymal & mean ${ }^{\dagger}$ & $48 \cdot 1$ & $48 \cdot 8$ & $50 \cdot 0$ & $51 \cdot 3$ & $53 \cdot 1$ & $50 \cdot 6$ & $0.151 \ddagger$ & 33 \\
\hline \multicolumn{10}{|c|}{ Progressive motility } \\
\hline Ejaculated & - & - & - & 3.58 & $3 \cdot 62$ & 3.48 & 3.00 & 0.073 & 33 \\
\hline Ejaculated & - & $3 \cdot 50$ & $3 \cdot 70$ & 3.62 & 3.54 & - & - & 0.046 & 12 \\
\hline Epididymal & meant & $3 \cdot 14$ & 3.08 & $3 \cdot 23$ & $3 \cdot 15$ & $3 \cdot 23$ & $3 \cdot 20$ & $0 \cdot 147$ & 33 \\
\hline \multicolumn{10}{|c|}{$\mathrm{CO}_{2}$ production $\left(\mu \mathrm{mol} / 10^{8}\right.$ cells $\left./ 3 \mathrm{~h}\right)$} \\
\hline Ejaculated & - & - & - & $2 \cdot 28$ & 1.80 & $1 \cdot 19$ & 0.62 & $0 \cdot 160$ & 33 \\
\hline Ejaculated & - & $2 \cdot 17$ & $2 \cdot 68$ & 2.45 & $2 \cdot 10$ & - & -1 & $0 \cdot 167$ & 12 \\
\hline Epididymal & - & 1.98 & $2 \cdot 37$ & $2 \cdot 37$ & $2 \cdot 19$ & 2.03 & 1.71) & 0.179 & 15 \\
\hline Epididymal & + & 1.73 & 2.59 & $2 \cdot 72$ & $2 \cdot 70$ & $2 \cdot 64$ & $2 \cdot 29$ & 0.179 & 13 \\
\hline Testicular & meant & 0.70 & 0.77 & 0.85 & 0.80 & 0.82 & 0.73 & 0.064 & 24 \\
\hline \multicolumn{10}{|c|}{ Lactate accumulated $\left(\mu \mathrm{mol} / 10^{8}\right.$ cells $\left./ 3 \mathrm{~h}\right)$} \\
\hline Ejaculated & - & - & - & 0.39 & 0.57 & 0.62 & 0.54 & 0.059 & 33 \\
\hline Ejaculated & - & $0 \cdot 12$ & 0.15 & 0.24 & 0.45 & - & - & 0.039 & 12 \\
\hline Epididymal & - & 0.37 & 0.44 & 0.48 & 0.54 & 0.56 & $0.55\}$ & 0.034 & 14 \\
\hline Epididymal & + & 0.47 & 0.58 & 0.60 & 0.60 & 0.57 & $0.54\}$ & 0.034 & 14 \\
\hline Testicular & mean $\dagger$ & 0.28 & 0.25 & 0.24 & 0.25 & 0.25 & 0.26 & 0.041 & 14 \\
\hline
\end{tabular}

* Standard error of the difference between means calculated from the error mean square of the analysis of variance.

+ Mean of values obtained with and without bicarbonate.

$¥$ On data transformed to the $\arcsin \sqrt{\text { percentage. }}$

$0.61 \pm 0.06$ at $\mathrm{pH} 7.6)$. There was a small but significant $(P<0.05)$ linear increase in the mean percentage of motile spermatozoa with increasing $\mathrm{pH}(53.5 \%$ at $\mathrm{pH} 7.2 ; 55.2 \%$ at $\mathrm{pH} 7.4$; and $56.3 \%$ at $\mathrm{pH} 7.6$ ).

Effect of osmotic pressure. The effect of osmotic pressure during incubation was studied in two experiments, the first associated with $\mathrm{pH}$ effects (see above) and an osmotic pressure range between 280 and $370 \mathrm{mosmol}$, and the second at $\mathrm{pH} 7.4$ between 230 and $310 \mathrm{mosmol}$.

At the end of the 3-h incubation the percentage of spermatozoa which were motile (Table 1) was greatest at $250 \mathrm{mosmol}(P<0.01$ for $\mathrm{L} ; P<0.05$ for $\mathrm{Q})$ and decreased $(P<0.05$ for $\mathrm{L})$ between 280 and 370 mosmol. Progressive motility was also maximal at 250 mosmol $(P<$ 0.001 for $\mathrm{Q}$ ), and decreased further above $310 \mathrm{mosmol}(P<0.001$ for $\mathrm{L}$ and $\mathrm{Q})$. The production of $\mathrm{CO}_{2}$ was maximal $(P<0.01$ for $Q)$ around 250 mosmol, and decreased linearly $(P<0.05)$ between 280 and 370 mosmol (Table 1). Lactate accumulation was greatest $(P<$ 0.001 for Q) at $310-340 \mathrm{mosmol}$, and was higher at 370 than at $280 \mathrm{mosmol}(P<0.001 \mathrm{for} L)$. In the second experiment lactate accumulation increased linearly $(P<0.001)$ between 220 and 310 mosmol, although there was a small but significant $(P<0.01)$ quadratic effect.

\section{Epididymal spermatozoa}

Spermatozoa from 4 boars were incubated over a range of osmotic pressures in Tris- $\mathrm{HCl}$ or phosphate buffers at $\mathrm{pH} 7.4$. 
Table 2. Effect of osmotic pressure and $6 \mathrm{~mm}$-bicarbonate on the metabolism of washed boar spermatozoa incubated for $3 \mathrm{~h}$ at $37^{\circ} \mathrm{C}$ in Tris- $\mathrm{HCl}$ buffer with glucose as substrate (values are for $10^{8}$ spermatozoa $/ 3 \mathrm{~h}$ )

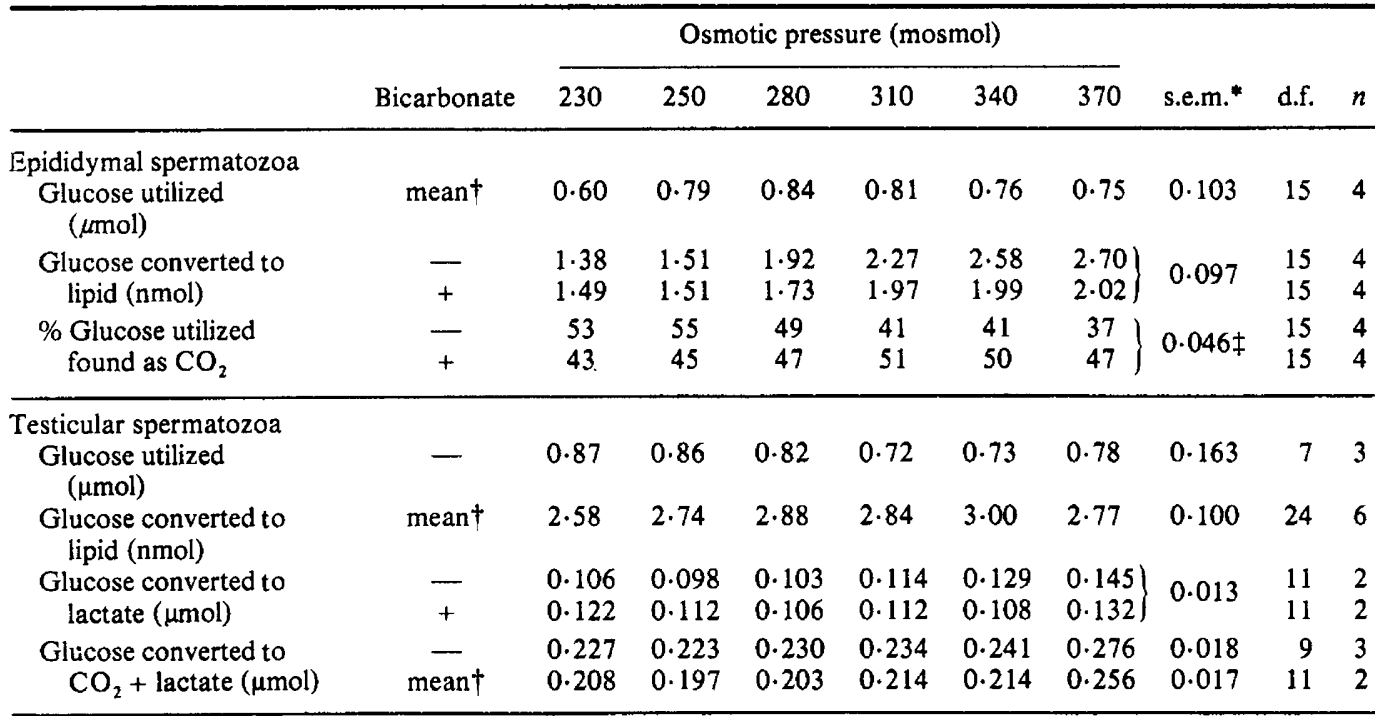

* Standard error of the difference between means calculated from the error mean square of the analysis of variance.

$\dagger$ Mean of the values obtained with and without bicarbonate.

$\ddagger$ On data transformed to angle $=\arcsin \sqrt{\text { percentage }}$ for the analysis of variance.

Effect of bicarbonate and osmotic pressure with $30 \mathrm{mM}$-Tris-HCl buffer. The osmotic pressure of the fluid from the cauda epididymidis (the supernatant after centrifuging) was about $335 \pm 10$ mosmol. For nearly all the variables measured there were large interactions between addition of bicarbonate and different boars and when applicable this has been allowed for in the statistical analyses. The peak value for percentage of motile spermatozoa was at $250 \mathrm{mosmol}$ in the presence of bicarbonate but was at 340 mosmol in its absence (bicarbonate $\times$ osmotic pressure interaction: $P<0.05$ for $\mathrm{L} \times \mathrm{Q}$ ). There was also an overall linear increase in percentage motile spermatozoa with rising osmotic pressure $(P<0.05)$. Bicarbonate and osmotic pressure had no significant effect on progressive motility (Table 1). Addition of bicarbonate resulted in the $\mathrm{pH}$ of the medium at the end of incubation $(\mathrm{pH} 7.37)$ being higher $(P$ $<0.001)$ than in its absence $(\mathrm{pH} 7.11)$.

The production of $\mathrm{CO}_{2}$ by epididymal spermatozoa (Table 1) was affected by the presence of bicarbonate. Therefore, although there was an overall quadratic effect of osmotic pressure $(P<$ 0.05 ), peak $\mathrm{CO}_{2}$ production occurred at $250-280 \mathrm{mosmol}$ in the absence of bicarbonate and at 250-340 mosmol in its presence (bicarbonate $\times$ osmotic pressure interaction: $P<0.05$ for $\mathrm{L} \times \mathrm{Q}$ ). Addition of bicarbonate at low osmotic pressures had no effect but increased $\mathrm{CO}_{2}$ production at higher osmotic pressures (i.e. a significant interaction of osmotic pressure and addition of bicarbonate: $P<0.001$ for $\mathrm{L} \times \mathrm{L}$ ).

Lactate accumulation, whether measured enzymically (Table 1) or as $\left[{ }^{14} \mathrm{C}\right]$ lactate from precursor $\left[{ }^{14} \mathrm{C}\right]$ glucose, showed a quadratic effect of osmotic pressure $(P<0.001)$. As with $\mathrm{CO}_{2}$ production, there was a linear $\times$ linear interaction of the effects of osmotic pressure and bicarbonate addition $(P<0.01)$ but addition of bicarbonate had a stimulatory action on lactate accumulation below 310 mosmol.

Lipid synthesis from glucose (Table 2) increased with rising osmotic pressure but the rate of increase was less when bicarbonate was included in the medium (osmotic pressure $\times$ bicarbonate 
interaction: $P<0.001$ for $\mathrm{L} \times \mathrm{L}$ ). Glucose utilization by epididymal spermatozoa was markedly affected by osmotic pressure, with a maximum at $280 \mathrm{mosmol}(P<0.05$ for $\mathrm{Q})$. Because of the lack of effect of addition of bicarbonate on glucose utilization, $\mathrm{CO}_{2}$ production as a percentage of glucose utilized was virtually unchanged in the presence of bicarbonate, but fell with increasing osmotic pressure in the absence of bicarbonate (Table 2: osmotic pressure $x$ bicarbonate interaction: $P<0.001$ for $\mathrm{L} \times \mathrm{L}$ ). The proportion of glucose utilized which accumulated as lactate $(36 \%)$ and as lactate $+\mathrm{CO}_{2}(83 \%)$ was constant under all conditions of incubation.

Table 3. Effect of buffer, 6 mM-bicarbonate, and osmotic pressure on the metabolism of glucose by washed spermatozoa from the cauda epididymidis of the toar (means for 4 boars, for $10^{8}$ spermatozoa $/ 3 \mathrm{~h}$ )

\begin{tabular}{|c|c|c|c|c|c|c|c|c|}
\hline Buffer & Bicarbonate & $\begin{array}{c}\text { Osmotic } \\
\text { pressure } \\
\text { (mosmol) }\end{array}$ & $\begin{array}{c}\mathrm{CO}_{2} \\
\text { formed } \\
(\mu \mathrm{mol})\end{array}$ & $\begin{array}{c}\text { Lactate } \\
\text { accumulated } \\
(\mu \mathrm{mol})\end{array}$ & $\begin{array}{l}\text { Glucose } \\
\text { utilized } \\
\text { ( } \mu \mathrm{mol})\end{array}$ & $\begin{array}{c}\text { \% glucose } \\
\text { utilized } \\
\text { found as } \\
\mathrm{CO}_{2}\end{array}$ & $\begin{array}{l}\text { \% glucose } \\
\text { utilized } \\
\text { found as } \\
\text { lactate }\end{array}$ & $\begin{array}{c}\text { Glucose } \\
\text { converted } \\
\text { to lipid } \\
(\mathrm{nmol})\end{array}$ \\
\hline \multirow[t]{2}{*}{ Tris } & 一 & $\begin{array}{l}250 \\
280 \\
310 \\
370\end{array}$ & $\begin{array}{l}2 \cdot 37 \\
2 \cdot 37 \\
2 \cdot 19 \\
1 \cdot 71\end{array}$ & $\begin{array}{l}0.44 \\
0.48 \\
0.54 \\
0.55\end{array}$ & $\begin{array}{l}0.68 \\
0.75 \\
0.79 \\
0.72\end{array}$ & $\begin{array}{l}55 \\
49 \\
41 \\
37\end{array}$ & $\begin{array}{l}36 \\
36 \\
35 \\
38\end{array}$ & $\begin{array}{l}1 \cdot 51 \\
2 \cdot 27 \\
2 \cdot 70\end{array}$ \\
\hline & + & $\begin{array}{l}250 \\
280 \\
310 \\
370\end{array}$ & $\begin{array}{l}2 \cdot 59 \\
2 \cdot 72 \\
2 \cdot 70 \\
2 \cdot 29\end{array}$ & $\begin{array}{l}0.58 \\
0.60 \\
0.60 \\
0.54\end{array}$ & $\begin{array}{l}0.89 \\
0.92 \\
0.83 \\
0.77\end{array}$ & $\begin{array}{l}45 \\
47 \\
51 \\
47\end{array}$ & $\begin{array}{l}33 \\
32 \\
39 \\
37\end{array}$ & $\begin{array}{l}1.51 \\
\frac{-}{1.97} \\
2.02\end{array}$ \\
\hline \multirow[t]{2}{*}{ Phosphate } & - & $\begin{array}{l}250 \\
280 \\
310 \\
370\end{array}$ & $\begin{array}{l}2.46 \\
2.01 \\
1.88 \\
1.14\end{array}$ & $\begin{array}{l}0.40 \\
0.44 \\
0.50 \\
0.57\end{array}$ & $\begin{array}{l}0.71 \\
0.70 \\
0.67 \\
0.57\end{array}$ & $\begin{array}{l}46 \\
44 \\
43 \\
26\end{array}$ & $\begin{array}{l}34 \\
32 \\
41 \\
53\end{array}$ & $\begin{array}{l}1.93 \\
2 \cdot 31 \\
2 \cdot 63\end{array}$ \\
\hline & + & $\begin{array}{l}250 \\
280 \\
310 \\
370\end{array}$ & $\begin{array}{l}3.09 \\
2.65 \\
2.67 \\
1.67\end{array}$ & $\begin{array}{l}0.49 \\
0.56 \\
0.54 \\
0.54\end{array}$ & $\begin{array}{l}0.91 \\
0.77 \\
0.84 \\
0.70\end{array}$ & $\begin{array}{l}53 \\
57 \\
49 \\
33\end{array}$ & $\begin{array}{l}28 \\
37 \\
34 \\
40\end{array}$ & $\begin{array}{l}2 \cdot 10 \\
2 \cdot 14 \\
2 \cdot 22\end{array}$ \\
\hline
\end{tabular}

Summary of the analyses of variance

\begin{tabular}{|c|c|c|c|c|c|c|c|}
\hline \multirow[b]{2}{*}{ Source of variation } & \multirow[b]{2}{*}{ d.f. } & \multicolumn{6}{|c|}{ Variance ratios } \\
\hline & & $\mathrm{CO}_{2}$ & $\begin{array}{c}\text { Lactate } \\
\text { accumulated }\end{array}$ & $\begin{array}{l}\text { Glucose } \\
\text { utilized }\end{array}$ & $\begin{array}{l}\% \text { glucose } \\
\text { as } \mathrm{CO}_{2}^{\dagger}\end{array}$ & $\begin{array}{l}\% \text { glucose } \\
\text { as lactate }\end{array}$ & Lipid \\
\hline A. Between buffers & 1 & $7 \cdot 46^{*}$ & 3.42 & $5 \cdot 92^{*}$ & 3.07 & 0.72 & $13 \cdot 25$ \\
\hline B. Bicarbonate & 1 & $72 \cdot 30^{* * *}$ & $23 \cdot 86^{* * *}$ & 24.67 & $9 \cdot 11^{* *}$ & 2.67 & $14 \cdot 39$ \\
\hline \multicolumn{8}{|l|}{ C. Osmotic pressure } \\
\hline L & 1 & $105 \cdot 11$ & 11.59 & $8 \cdot 14^{* *}$ & 33.78 & $11 \cdot 39^{* *}$ & 69.90 \\
\hline $\mathrm{Q}$ & 1 & $14 \cdot 09^{* *}$ & 1.74 & 2.44 & $6.02^{*}$ & 0.68 & 2.04 \\
\hline D. Amongst boars & 3 & $231 \cdot 23^{* * *}$ & $135 \cdot 30^{*}$ & $83 \cdot 34^{*}$ & $62 \cdot 72^{* * *}$ & $56 \cdot 24^{* * * *}$ & $38 \cdot 13^{* *}$ \\
\hline \multicolumn{8}{|l|}{$\mathrm{A} \times \mathrm{C}$} \\
\hline \multicolumn{8}{|l|}{$\mathrm{B} \times \mathrm{C}$} \\
\hline $\mathbf{L} \times \mathbf{L}$ & 1 & 0.90 & $10.55^{* *}$ & $2 \cdot 30$ & $4 \cdot 17$ & 0.35 & $17 \cdot 62^{* * *}$ \\
\hline $\mathbf{B} \times \mathbf{D}$ & 3 & 1.02 & $14.81^{* * *}$ & $3.53^{*}$ & 0.14 & 1.59 & $1 \cdot 16$ \\
\hline$C \times D$ & 9 & $3 \cdot 01^{*}$ & $3.92^{* *}$ & 2.04 & 0.30 & 0.80 & $2 \cdot 69^{*}$ \\
\hline $\begin{array}{l}\text { Higher-order boar } \\
\text { interactions (error } \\
\text { mean square) }\end{array}$ & 26 & $\underline{0.0627}$ & $\underline{0.0027}$ & 0.0108 & $\underline{0.0059}$ & $\underline{0.0068}$ & $\underline{0.0452 \ddagger}$ \\
\hline
\end{tabular}

${ }^{*} P<0.05 ;{ }^{* *} P<0.01 ;{ }^{* * *} P<0.001$ (using the higher-order interactions where appropriate).

$\dagger$ On data transformed to the arcsin $\sqrt{\text { percentage. }}$

$\ddagger$ For 21 d.f. 
Table 4. Effect of buffer, $6 \mathrm{~mm}$-bicarbonate, and osmotic pressure on the metabolism of washed testicular spermatozoa of the boar (values are for $10^{8}$ spermatozoa/ $3 \mathrm{~h} ; n=5$ for $\mathrm{CO}_{2}, 3$ for lactate and 4 for lipid)

\begin{tabular}{|c|c|c|c|c|c|}
\hline Buffer & Bicarbonate & $\begin{array}{l}\text { Osmotic pressure } \\
\text { (mosmol) }\end{array}$ & $\begin{array}{c}\mathrm{CO}_{2} \text { formed } \\
(\mu \mathrm{mol})\end{array}$ & $\begin{array}{c}\text { Lactate } \\
\text { accumulated } \\
(\mu \mathrm{mol})\end{array}$ & $\begin{array}{c}\text { Glucose converted } \\
\text { to lipid } \\
\text { (nmol) }\end{array}$ \\
\hline \multirow[t]{2}{*}{ Tris } & - & $\begin{array}{l}250 \\
310 \\
370\end{array}$ & $\begin{array}{l}0.90 \\
1.03 \\
0.87\end{array}$ & $\begin{array}{l}0.26 \\
0.25 \\
0.24\end{array}$ & $\begin{array}{l}3 \cdot 11 \\
3 \cdot 18 \\
3 \cdot 02\end{array}$ \\
\hline & + & $\begin{array}{l}250 \\
310 \\
370\end{array}$ & $\begin{array}{l}0.81 \\
0.90 \\
0.78\end{array}$ & $\begin{array}{l}0.24 \\
0.27 \\
0.28\end{array}$ & $\begin{array}{l}2.87 \\
3.09 \\
2.96\end{array}$ \\
\hline \multirow[t]{2}{*}{ Phosphate } & - & $\begin{array}{l}250 \\
310 \\
370\end{array}$ & $\begin{array}{l}0.70 \\
1.06 \\
0.96\end{array}$ & $\begin{array}{l}0.21 \\
0.29 \\
0.23\end{array}$ & $\begin{array}{l}3 \cdot 75 \\
4.49 \\
4 \cdot 32\end{array}$ \\
\hline & + & $\begin{array}{l}250 \\
310 \\
370\end{array}$ & $\begin{array}{l}0.72 \\
0.77 \\
0.69\end{array}$ & $\begin{array}{l}0.22 \\
0.24 \\
0.21\end{array}$ & $\begin{array}{l}3 \cdot 65 \\
4 \cdot 14 \\
3 \cdot 31\end{array}$ \\
\hline
\end{tabular}

\begin{tabular}{|c|c|c|c|c|c|c|}
\hline \multicolumn{7}{|c|}{ Summary of the analyses of variance } \\
\hline \multirow[b]{2}{*}{ Source of variation } & \multicolumn{2}{|r|}{$\mathrm{CO}_{2}$} & \multicolumn{2}{|r|}{ Lactate } & \multicolumn{2}{|r|}{ Lipid } \\
\hline & d.f. & Variance ratio & d.f. & Variance ratio & d.f. & Variance ratio \\
\hline A. Between buffers & 1 & $5 \cdot 64$ & 1 & 3.02 & 1 & $28 \cdot 40^{* * *}$ \\
\hline B. Bicarbonate & 1 & $27 \cdot 23^{* * *}$ & 1 & 0.00 & 1 & $3 \cdot 31$ \\
\hline \multicolumn{7}{|l|}{ C. Osmotic pressure } \\
\hline L & 1 & 1.60 & 1 & 0.01 & 1 & 0.09 \\
\hline $\mathrm{Q}$ & 1 & $22 \cdot 53^{* *}$ & 1 & 0.97 & 1 & 3.84 \\
\hline D. Amongst boars & 4 & $116.55^{* * *}$ & 2 & $7.94^{* *}$ & 3 & $56 \cdot 72^{* * *}$ \\
\hline $\mathrm{A} \times \mathrm{B}$ & 1 & 1.88 & 1 & $1 \cdot 34$ & 1 & $1 \cdot 12$ \\
\hline$A \times C$ & 2 & 2.49 & 2 & 1.04 & 2 & 0.69 \\
\hline$A \times D$ & 4 & $11 \cdot 27^{* * *}$ & 2 & $7 \cdot 48^{* *}$ & 3 & $14 \cdot 62^{* * *}$ \\
\hline$B \times C$ & 2 & 3.58 & 2 & 0.19 & 2 & 0.45 \\
\hline$B \times D$ & 4 & $3.88^{*}$ & 2 & 0.35 & 3 & $2 \cdot 10$ \\
\hline$C \times D$ & 8 & $2.63^{*}$ & 4 & 0.53 & 6 & 0.91 \\
\hline \multicolumn{7}{|l|}{$\mathrm{A} \times \mathrm{B} \times \mathrm{C}$} \\
\hline $\mathrm{L} \times \mathrm{L} \times \mathrm{L}$ & 1 & $4 \cdot 63^{*}$ & 1 & 0.05 & 1 & 0.14 \\
\hline $\mathbf{L} \times \mathbf{L} \times \mathbf{Q}$ & 1 & 1.01 & 1 & 0.53 & 1 & 1.62 \\
\hline $\begin{array}{l}\text { Higher-order interactions (error mean } \\
\text { square) }\end{array}$ & 25 & 0.0114 & 13 & 0.0031 & 16 & 0.2601 \\
\hline
\end{tabular}

${ }^{*} P<0.05 ;{ }^{* *} P<0.01 ;{ }^{* * *} P<0.001$ (using the higher-order interaction where appropriate).

Comparison of Tris- $\mathrm{HCl}$ and phosphate buffers. There were no significant effects on the percentage of motile spermatozoa or on progressive sperm motility. The $\mathrm{pH}$ of the medium at the end of incubation was similar in Tris + bicarbonate $(\mathrm{pH} \mathrm{7.37)}$ and phosphate + bicarbonate $(\mathrm{pH}$ $7.31)$ but fell more $(P<0.05)$ in phosphate $(\mathrm{pH} \mathrm{6.92)}$ than in Tris $(\mathrm{pH} \mathrm{7.08)}$.

The significant effects obtained witi the two buffers are presented in Table 3. Carbon dioxide production from glucose was increased (mean $25 \%$ ) by the addition of bicarbonate. Increasing osmotic pressure resulted in a greater depression of $\mathrm{CO}_{2}$ production with the phosphate buffer (decrease of $50 \%$ ) than with Tris buffer (decrease of $20 \%$ ). Accumulation of lactate was increased by addition of bicarbonate at low osmotic pressure but was unaffected at high osmotic pressure. Lipid formation from glucose was greater in phosphate buffer than in Tris buffer at 250 mosmol, but the amounis formed were similar in the two buffers at 310 and 370 mosmol. Addition of bicarbonate had no effect on lipid synthesis at 250 mosmol but depressed lipid synthesis at 310 and 370 mosmol. Glucose utilization was greater with Tris than with phosphate 
buffer. Bicarbonate enhanced glucose utilization but the increase varied amongst boars. As the osmotic pressure increased there was less utilization of glucose. The percentage of glucose utilized and found as $\mathrm{CO}_{2}$ fell with high osmotic pressure, the decrease being greater with phosphate than with Tris buffer, while that found as lactate increased with increasing osmotic pressure because lactate formed from glucose remained constant. However, the proportion of glucose disappearing that was found as $\mathrm{CO}_{2}+$ lactate was high (81\%) and constant under all conditions.

\section{Testicular spermatozoa}

The rete testis fluid of the boar had an osmotic pressure of about $273 \pm 11$ mosmol $(n=5)$. These spermatozoa showed no progressive motility, and progressive motility was not initiated by any treatment during incubation at $37^{\circ} \mathrm{C}$ for $3 \mathrm{~h}$ at $\mathrm{pH} 7.4$.

The results with Tris buffer are shown in Tables 1 and 2 and for the comparisons of Tris and phosphate buffers in Table 4.

Production of $\mathrm{CO}_{2}$ was slightly depressed $(P<0.01$ for $Q)$ at high or low osmotic pressures (Table 1). A similar mean trend in the comparison of buffers (Table 4) was not statistically significant as it did not occur for all boars. Although total lactate accumulation (i.e. enzymic estimation) was not affected by osmotic pressure, addition of bicarbonate or by type of buffer, there were some small but statistically significant changes in the accumulation of $\left[{ }^{14} \mathrm{C}\right]$ lactate from $\left[{ }^{14} \mathrm{C}\right]$ glucose (Table 2). In the absence of bicarbonate, lactate formed from glucose increased with rising osmotic pressure (bicarbonate $\times$ osmotic pressure interaction: $P<0.05$ for $\mathrm{L} \times \mathrm{L})$. Overall lactate production from glucose was least at $250-280 \mathrm{mosmol}(P<0.05$ for Q). Glucose converted to lactate $+\mathrm{CO}_{2}$ was least at $250 \mathrm{mosmol}$ and then increased as the osmotic pressure rose $(P<0.01$ for $\mathrm{L}$ and $\mathrm{Q})$. Because of the small amount of glucose utilized the errors in the estimation of the amount of glucose utilized were large. Glucose utilized $(0.72 \pm$ $0.16 \mu \mathrm{mol} / 10^{8}$ spermatozoa over $3 \mathrm{~h}$ ), lactate formed from glucose as a percentage of glucose utilized $(20 \pm 2.4 \%)$, and lactate formed from glucose $+\mathrm{CO}_{2}$ formed from glucose as a percentage of glucose utilized $(35 \pm 4.8 \%)$ were not altered by osmotic pressure changes or by addition of bicarbonate. No chromatography was carried out after incubation in phosphate buffer. Lipid production from glucose increased as the osmotic pressure was raised from 230 to 340 mosmol but then fell $(P<0.01$ for $\mathrm{L}$ and $\mathrm{Q})$.

\section{Discussion}

The changes in metabolism of boar spermatozoa as they mature are similar to those found in other species (see Voglmayr, 1975). Under optimal incubation conditions, production of $\mathrm{CO}_{2}$ and lactate increased with maturation (Table 1). Conversely, synthetic capacity, as measured by incorporation of glucose into lipid, was greater in testicular than in epididymal spermatozoa (Table 2). As with other species, most of the glucose utilized by mature boar epididymal spermatozoa of boars was converted to $\mathrm{CO}_{2}$ and lactate, but this conversion by boar testicular spermatozoa was lower than that by the testicular cells of other species (Voglmayr, 1975). During maturation boar spermatozoa become more sensitive to changes in incubation conditions, whether $\mathrm{CO}_{2}$ and lactate production are expressed as absolute values or as percentages.

Osmotic pressure changes were carried out by changing the amount of $\mathrm{NaCl}$. With Tris buffer, at the two extremes of 230 and 370 mosmol, the $\mathrm{NaCl}$ added was about 70 and $140 \mathrm{~mm}$ respectively. The change in the $\mathrm{Na}: \mathrm{K}$ ratio thus caused would not have affected the motility of the boar spermatozoa (Boender, 1976). Although chloride levels were also changed, it is 
assumed that any effects seen were due to osmotic pressure per se, a view supported by the data of sperm motility at different osmotic pressures. Low osmotic pressures stimulated motility, as observed previously with stored boar spermatozoa (Stevermer et al., 1964). The effects of osmotic pressure on motility were smaller with epididymal spermatozoa.

The effects of osmotic pressure on $\mathrm{CO}_{2}$ and lactate production were greatest with ejaculated spermatozoa, and minimal with testicular cells. Glucose incorporation into lipid was more affected by osmotic pressure in epididymal than in testicular spermatozoa. This may be related to the increasing susceptibility to cold shock of spermatozoa as they mature (Lasley \& Bogart, 1944; Voglmayr et al., 1967).

Decreased $\mathrm{CO}_{2}$ production with hyperosmolality supports the suggestion with osmotic pressure affects the morphology of the mitochondria, as it does the volume of the whole cell (Drevius, 1972). The increased lactate and lipid accumulation with hyperosmolar conditions may not be similarly affected because lipid synthesis occurs in the cytoplasm and glycolytic enzymes are concentrated in the tail (Mohri, Mohri \& Ernster, 1965). Inhibition of oxidative metabolism in the presence of increased glycolysis could in itself increase lipid synthesis by accumulation of precursors. Also, reduced oxidative metabolism may have reduced degradation of lactate and lipid, thus giving an apparent increase in their formation. However, $\mathrm{CO}_{2}$ and lactate production are both related to motility, and the osmolality at which the motility of ejaculated spermatozoa was maintained included the peaks for both $\mathrm{CO}_{2}$ and lactate formation, i.e. as $\mathrm{CO}_{2}$ production is decreased glycolysis increases to maintain the energy supply. However, the increased motility of ejaculated cells under hypo-osmolar conditions is consistent with oxidation rather than glycolysis supplying the energy for progressive motility of boar spermatozoa (Nevo, Polge \& Frederick, 1970).

The effects on matured spermatozoa of the addition of sodium bicarbonate are likely to be partly due to the greater buffering capacity that it confers. This may apply particularly to the intracellular medium (Salisbury, VanDemark, Lodge \& Cragle, 1960), and would be less important in testicular spermatozoa because of their lower lactate production. A direct action of bicarbonate on sperm metabolism cannot be ruled out because bicarbonate is involved in sperm metabolic pathways (Mounib \& Eisan, 1968; O'Shea \& Wales, 1970). The interactions of bicarbonate and osmotic pressure with respect to $\mathrm{CO}_{2}$ and lactate production by epididymal cells are such as to decrease the detrimental effects of increasing and decreasing osmotic pressure respectively. The interaction of osmotic pressure and bicarbonate on lipid synthesis and progressive motility may also be related to their interactive effects on $\mathrm{CO}_{2}$ production. Bicarbonate caused both increased glycolysis and respiration of ejaculated ram spermatozoa (Wales \& Murdoch, 1971) but not in all circumstances.

The greater energy available to epididymal spermatozoa in Tris buffer may be related to the differential ionic permeability of membranes because Tris can penetrate cell membranes (Omachi, Macey \& Waldeck, 1961) and may act as an intracellular buffer. The entry of phosphate into spermatozoa is controlled by the plasma membrane, and high levels of extracellular phosphate do not always result in increased cellular phosphate levels (Babcock, First \& Lardy, 1975). Phosphate has also been reported to inhibit hexokinase in muscle (Leuck \& Fromm, 1974). In other species Tris has been reported to be better than phosphate for maintaining sperm motility (Jones \& Foote, 1972).

This study of conditions during incubation in vitro has shown that boar spermatozoa become more sensitive to their environment as they mature. It is tempting to infer that this may result from some form of membrane transformation. The diminution of lipid (Grogan, Mayer \& Sikes, 1966; Johnson, Pursel \& Gerrits, 1972) and the possible change in fatty acid composition (Voglmayr, 1975) during transit through the epididymis could be related to such a transformation. This decrease in resistance of spermatozoa to environmental changes with maturity parallels their decreased resistance to cold shock (Lasley \& Bogart, 1944), which is also a membrane phenomenon. 


\section{References}

Babcock, D.F., First, N.L. \& Lardy, H.A. (1975) Transport mechanism for succinate and phosphate localized in the plasma membrane of bovine spermatozoa. J. biol. Chem. 250, 6488-6495.

Blackshaw, A.W. \& Emmens, C.W. (1951) The interaction of $\mathrm{pH}$, osmotic pressure and electrolyte concentration on the motility of ram, bull and human spermatozoa. J. Physiol., Lond. 114, 16-26.

Boender, J. (1976) The effects of $\mathrm{Na}^{+}, \mathrm{K}^{+}$and ouabain on the motility and ATP content of boar spermatozoa. Proc. K. ned. Akad. Wet., Series C 79, 1333.

Cochran, W.G. \& Cox, G. M. (1957) Experimental Designs, 2nd edn. John Wiley \& Sons, New York.

Drevius, L.-O. (1972) Bull spermatozoa as osmometers. J. Reprod. Fert. 28, 29-39.

Duncan, D.B. (1955) Multiple range and multiple F tests. Biometrics 11, 1-42.

Edwards, E.M., Dacheux, J.-L. \& Waites, G.M.H. (1976) Effects of $\alpha$-chlorohydrin on the metabolism of testicular and epididymal spermatozoa of rams. $J$. Reprod. Fert. 48, 265-270.

Fisher, R.A. \& Yates, F. (1963) Statistical Tables for Biological, Agricultural and Medical Research, 6th edn. Longmans, London.

Grogan, D.E., Mayer, D.T., \& Sikes, J.D. (1966) Quantitative differences in phospholipids of ejaculated spermatozoa and spermatozoa from three levels of the epididymis of the boar. J. Reprod. Fert. 12, 431-436.

Johnson, L.A., Pursel, V.G. \& Gerrits, R.J. (1972) Total phospholipid and phospholipid fatty acids of ejaculated and epididymal semen and seminal vesicle fluids of boars. J. Anim. Sci. 35, 398-403.

Jones, R.C. \& Foote, R.H. (1972) Effect of osmolality and phosphate, 'TRIS', 'TES', 'MES', and 'HEPES' hydrogen ion buffers on the motility of bull spermatozoa stored at $37^{\circ} \mathrm{C}$ or $5^{\circ} \mathrm{C}$. Aust. J. biol. Sci. 25, 1047-1055.

Lasley, J.F. \& Bogart, R. (1944) Some factors affecting the resistance of ejaculated and epididymal spermatozoa of the boar to different environmental conditions. Am. J. Physiol. 141, 619-624.

Leuck, J.D. \& Fromm, H.J. (1974) Kinetics, mechanism and regulation of rat skeletal muscle hexokinase. $J$. biol. Chem. 249, 1341-1347.

Levine, N. \& Marsh, D.J. (1971) Micropuncture studies of the electro-chemical aspects of fluid and electrolyte transport in individual seminiferous tubules, the epididymis and the vas deferens in rats. $J$. Physiol., Lond. 213, 557-570.
Mann, T. (1975) Biochemistry of semen. In Handbook of Physiology, Section 7: Endocrinology Vol. 5, pp. 461-471. Eds D. W. Hamilton \& R. O. Greep. American Physiological Society, Washington, D.C.

Mohri, H., Mohri, T. \& Ernster, L. (1965) Isolation and enzymic properties of the midpiece of bull spermatozoa. Expl Cell Res. 38, 217-246.

Mounib, M.S. \& Eisan, J.S. (1968) Carbon dioxide fixation by spermatozoa of cod. Comp. Biochem. Biophys. 25, 703-709.

Nevo, A.C., Polge, C. \& Frederick, G. (1970) Aerobic and anaerobic metabolism of boar spermatozoa in relation to their motility. J. Reprod. Fert. 22, 109118.

Omachi, A., Macey, R.l. \& Waldeck, J.G. (1961) Permeability of cell membranes to amine buffers and their effects on electrolyte transport. Ann. N.Y. Acad. Sci. 92, 478-485.

O'Shea, T. \& Wales, R.G. (1970) Studies of the fixation of carbon dioxide by washed ram spermatozoa. Aust. J. biol. Sci. 23, 889-901.

Paquignon, M., Dacheux, J.-L. \& Courot, M. (1977) Effet de différentes solutions de déconglélation sur le pouvoir fécondant des spermatozoïdes de verrat. Journées de la Recherche porcine en France, pp. 1518.

Salisbury, G.W., VanDemark, N.L., Lodge, J.R. \& Cragle, R.G. (1960) Inhibition of spermatozoan metabolism by $\mathrm{pCO}_{2}, \mathrm{pH}, \mathrm{K}$ ion and antibacterial compounds. Am. J. Physiol. 198, 659-664.

Stevermer, E.J., First, N.L. \& Hoekstra, W.G. (1964) Effect of osmotic pressure on boar spermatozoa. $J$. Anim. Sci. 23, 67-70.

Voglmayr, J.K. (1975) Metabolic changes in spermatozoa during epididymal transit. In Handbook of Physiology, Section 7: Endocrinology, Vol. 5, pp. 437-451. Eds D. W. Hamilton \& R. O. Greep. American Physiological Society, Washington, D.C.

VogImayr, J.K., Waites, G.M.H. \& Setchell, B.P. (1966) Studies on spermatozoa collected directly from the testis of the conscious ram. Nature, Lond. 210, 861863.

Voglmayr, J.K., Scott, T.W., Setchell, B.P. \& Waites, G.M.H. (1967) Metabolism of testicular spermatozoa and characteristics of testicular fluid collected from conscious rams. J. Reprod. Fert. 14, 87-99.

Wales, R.G. \& Murdoch, R.N. (1971) Factors influencing the response of ram spermatozoa to bicarbonate and carbon dioxide. Aust. J. biol. Sci. 24, 345-354. 